\title{
Phosphorothioate-modified antisense oligonucleotides against human telomerase reverse transcriptase sensitize cancer cells to radiotherapy
}

\author{
FEI CAO $^{1 *}$, XIAOPING JU ${ }^{1 *}$, DI CHEN ${ }^{1,2 *}$, LINGONG JIANG ${ }^{1}$, XIAOFEI ZHU ${ }^{1}$, \\ SHUIWANG QING ${ }^{1}$, FANG FANG ${ }^{1}$, YUXIN SHEN ${ }^{1}$, ZHEN JIA ${ }^{1}$ and HUOJUN ZHANG ${ }^{1}$ \\ ${ }^{1}$ Department of Radiation Oncology, Shanghai Changhai Hospital; ${ }^{2}$ International Joint Cancer \\ Institute, Second Military Medical University, Shanghai 200433, P.R. China
}

Received May 26, 2016; Accepted April 4, 2017

DOI: $10.3892 / \mathrm{mmr} .2017 .6778$

\begin{abstract}
Emergence of resistance, unavoidable systemic toxicity and unsatisfactory efficacy arethe main obstacles for traditional cancer therapy. Combination with phosphorothioate modified antisense oligonucleotides (PS-ASODN) against human telomerase reverse transcriptase (hTERT) may enhance the therapeutic effect of irradiation. However, the effect of PS-ASODN against hTERT on the anti-tumor effects of irradiation in liver cancer remain unclear. In the current study, Walker 256 cells were transfected with hTERT PS-ASODN. Cell proliferation and cell viability were measured using the MTT assay and cell senescence was examined by SA- $\beta$-gal staining. Telomerase activity was determined by telomeric repeat amplification protocol-polymerase chain reaction-ELISA. Cell apoptosis was assayed by flow cytometry and DNA damage was determined by the comet assay. The PS-ASODN was demonstrated to have an inhibitory effect on cell proliferation and accelerated effect on cell senescence by inhibiting telomerase activity. PS-ASODN promoted the irradiation-induced inhibition of cell viability and telomerase activity, and irradiation-induced DNA damage and cell apoptosis via the activation of apoptosis-associated proteins. Taken together, these results indicated that combined treatment of PS-ASODN with irradiation significantly enhanced tumor inhibition. Therefore, PS-ASODN provides an experimental foundation for gene therapy and is proposed for application in clinical treatment of liver cancer combined with radiotherapy.
\end{abstract}

Correspondence to: Professor Huojun Zhang, Department of Radiation Oncology, Shanghai Changhai Hospital, Second Military Medical University, 168 Changhai Road, Shanghai 200433, P.R. China E-mail: chyyzhj@163.com

*Contributed equally

Key words: phosphorothioate modified antisense oligonucleotides, radiosensitivity, human telomerase reverse transcriptase, telomerase, liver cancer

\section{Introduction}

Cancerhas a large influence on human health and economy. Despite the fact that progress has been made in understanding cancer, it remains one of the leading causes of mortality $(1,2)$. Traditional cancer therapies including surgery, radiotherapy and chemotherapy, aim to destroy the tumor and leave normal tissue intact as much as is possible (3). However, the emergence of resistance to these therapies remains a challenge for successful treatment of cancer. Given the unsatisfactory efficacy and unavoidable systemic toxicity of traditional treatment, gene therapy has been investigated as a gene transcription and translation intervention, serving important roles for tumor growth, spread, survival and therapy resistance (4).

As a special type of RNA nuclear protease, telomerase synthesizes telomeric DNA sequences that provide tandem GT-rich repeats (TTAGGG) to compensate for telomere shortening $(5,6)$. Activated telomerase can be observed in more than $90 \%$ of cancer cases and beconsidered to permit tumor cell immortalization and promote cell malignant transformation $(7,8)$. Therefore, telomerase can be used as a potential target for gene therapy.

As the most important regulator of telomerase activity, human telomerase reverse transcriptase (hTERT) is a catalytic subunit of telomerase and processes telomere ends, which are over expressed in greater than $90 \%$ of tumor cells and contribute to tumor cell proliferation (8). Previous studies have demonstrated that antisense oligodeoxynucleotide (ASODN) gene therapy against hTERT may effectively inhibit telomerase activity and tumor growth $(9,10)$.

In the current study, a phosphorothioate ASODN (PS-ASODN) against hTERT was used to treat Walker 256 cells. The inhibitory effect and the mechanism of the PS-ASODN were explored in the Walker 256 cells to provide novel strategies for cancer gene therapy.

\section{Materials and methods}

Cell culture. Walker 256 cells were purchased from Shanghai Institute of Pharmaceutical Industry (Shanghai, China) and cultured in RPMI-1640 medium (Gibco; Thermo Fisher 
Scientific, Inc., Waltham, MA, USA) that contained 10\% (v/v) fetal bovine serum (Gibco; Thermo Fisher Scientific, Inc.), $100 \mathrm{U} / \mathrm{ml}$ penicillin and $100 \mu \mathrm{g} / \mathrm{ml}$ streptomycin, within a humidified at mosphere containing $5 \% \mathrm{CO}_{2}$ at $37^{\circ} \mathrm{C}$.

Cell transfection. The hTERT-targeted PS-ASODN was purchased from Shanghai Biotechnology Corporation (Shanghai, China). Walker 256 cells were transiently transfected with hTERT-targeted PS-ASODN using Lipofectamine ${ }^{\circledR} 2000$ Transfection reagent (Invitrogen; Thermo Fisher Scientific, Inc.).

Cell proliferation and viability assay. Walker 256 cells were seeded onto 96 -cell plates and incubated at $37^{\circ} \mathrm{C}$ overnight. For the cell proliferation assay, cells were treated with PS-ASODN at a final concentration of $0,1,2,3,4$ and $5 \mu \mathrm{mol} / 1$ for 1,3 and 7 days, respectively. For cell viability assay, cells were treated with $5 \mu \mathrm{mol} / 1 \mathrm{PS}-\mathrm{ASODN}$ for $24 \mathrm{~h}$ and then irradiation (IR) was performed by using an RS $2000 \mathrm{X}$-ray Biological Irradiator (Rad Source, Suwanee, GA, USA) at doses of 0, 2, 4,6 , and 8 Gy for $24 \mathrm{~h}$. MTT solution $(20 \mu \mathrm{l})$ was added into each well and the plates were incubated for $4 \mathrm{~h}$ at $37^{\circ} \mathrm{C}$. Then cells were exposed to $150 \mu \mathrm{l}$ DMSO and incubated for $10 \mathrm{~min}$. The optical density at $490 \mathrm{~nm}$ was read by an enzyme-linked immunosorbent assay (ELISA) reader.

Senescence-associated $\beta$-gal staining. Walker 256 cells were treated with $5 \mu \mathrm{mol} / \mathrm{l}$ PS-ASODN for 5 days. Senescence-associated $\beta$-gal (SA- $\beta$-gal) activity was performed using SA- $\beta$-gal staining kit (BeyotimeInstitute of Biotechnology, Haimen, China). Briefly, following removal of the RPMI-1640 medium, Walker 256 cells were washed with PBS and fixed with $2 \%$ form aldehyde and $0.2 \%$ glutaraldehyde for $10 \mathrm{~min}$. Subsequently, cells were incubated with fresh SA- $\beta$-gal stain solution overnight at $37^{\circ} \mathrm{C}$ (without $\mathrm{CO}_{2}$ ) following washing with PBS. After staining, cells were photographed using a microscope (IX73; Olympus Corporation, Tokyo, Japan), and the percentage of senescence cell was determined via counting five random fields.

Telomerase activity assay. Walker 256 cells were lysed with ice-cold lysis buffer (Takara Bio, Inc., Otsu, Japan) and centrifuged at $12,000 \mathrm{x}$ g for $30 \mathrm{~min}$ at $4^{\circ} \mathrm{C}$. The Bicinchoninic Acid (BCA) Protein Assay kit (Takara Bio, Inc.) was used to measure protein concentration. Telomerase activity assay was measured using the telomeric repeat amplification protocol (TRAP) with the TeloTAGGG Telomerase PCR ELISA kit (Roche Diagnostics, Basel, Switzerland) according to the manufacturer's instructions.

Cell apoptosis assay. Walker 256 cells were treated with PS-ASODN at final concentrations of $0,1,3$ and $5 \mu \mathrm{mol} / 1$ for $24 \mathrm{~h}$, respectively, then IR was performed using the RS 2000 X-ray Biological Irradiator at doses of 6 Gy for $24 \mathrm{~h}$. Cell apoptosis following radiation treatment was determined using the Annexin V-fluorescein isothiocyanate (FITC)/propidium iodide (PI) apoptotic cell detection kit (BD Biosciences, Franklin Lakes, NJ, USA) according to manufacturer's protocol. The percentage of apoptotic cells was determined via flow cytometry based on Annexin V/PI stain.
Western blot analysis. Walker 256 cells were treated with PS-ASODN at final concentrations of $0,1,3$ and $5 \mu \mathrm{mol} / 1$ for $24 \mathrm{~h}$, respectively, then IR was performed using theRS 2000 $\mathrm{X}$-ray Biological Irradiator at doses of $6 \mathrm{~Gy}$ for $24 \mathrm{~h}$. Cells were collected and lysed by ice-cold lysis buffer (Takara Bio, Inc.). Protein concentrations were determined using the BCA Protein Assay kit (Takara Bio, Inc.). Then, protein extracts were separated using $12 \%$ SDS-PAGE and transferred onto polyvinylidene difluoride (PVDF) membranes. Following incubated with 5\% nonfat milk, the membranes were incubated with polyclonal rabbit anti-caspase 3 (1:1,000; cat. no. ab13585; Abcam, Cambridge, MA, USA) or polyclonal rabbit anti-caspase 9 antibodies (1:1,000; cat. no. 9502; Cell Signaling Technology, Inc., Danvers, MA, USA) overnight at $4^{\circ} \mathrm{C}$. Membranes were then incubated with horseradish peroxidase-conjugated secondary antibodies $(1: 5,000$; cat. no. ab181658; Abcam) for $1 \mathrm{~h}$ at room temperature. Finally, the membranes were visualized using ECL Chemiluminescent Substrate Reagent kit (Thermo Fisher Scientific, Inc.).

Comet assay. DNA damage was determined using a comet assay. Walker 256 cells were treated with PS-ASODN at final concentrations of $0,1,3$ and $5 \mu \mathrm{mol} / 1$ for $24 \mathrm{~h}$, respectively, then IR was performed using the RS $2000 \mathrm{X}$-ray Biological Irradiator at doses of $6 \mathrm{~Gy}$ for $24 \mathrm{~h}$. Cells were collected and mixed with $0.5 \%$ low melting agarose. Following layeringonto agarose-coated slides, the slides were immersed in lysis buffer overnight at $4^{\circ} \mathrm{C}$. Subsequently, slides were incubated in electrophoresis buffer for $10 \mathrm{~h}$. Following electrophoresis, slides were neutralized with $0.4 \mathrm{~mol} / \mathrm{l}$ Tris- $\mathrm{HCl}$ buffer $(\mathrm{pH}=7.5)$ twice per $5 \mathrm{~min}$ and then immersed in $100 \%$ ethanol for $20 \mathrm{~min}$. After being air-dried, slides were stained with $2 \mu \mathrm{g} / \mathrm{ml}$ ethidium bromide for $15 \mathrm{~min}$. Finally, slides were observed under a confocal microscope.

Statistical analysis. Data were expressed as the mean \pm standard deviation. GraphPad Prism 5 software (GraphPad Software, Inc., La Jolla, CA, USA) was used for the statistical tests. The data were compared between two groups using the two-tailed Student's t-test and between multiple groups using two-way analysis of variance followed by Tukey's post hoc test. $\mathrm{P}<0.05$ was considered to indicate a statistically significant difference.

\section{Results}

Inhibition of PS-ASODN on Walker 256 cell proliferation. The proliferation of Walker 256 cells was inhibited by treating with PS-ASODN (1-5 $\mu \mathrm{M}$ ) on days $0,1,3$ and 7 (Fig. 1). The proliferation rate between the PS-ASODN group and control group was significant. The proliferation rate decreased as the time and PS-ASODN concentration increased, which indicated that PS-ASODN inhibited Walker 256 cells proliferation in a dose- and time-dependent manner.

PS-ASODN induced acceleration of cell senescence by inhibiting telomerase activity. SA- $\beta$-gal commonly acts as a biomarker of replicative senescence due to its overexpression in pre-senescent and senescent cells. In order to study the effect of PS-ASODN on senescence of Walker 256 cells, SA- $\beta$-gal 


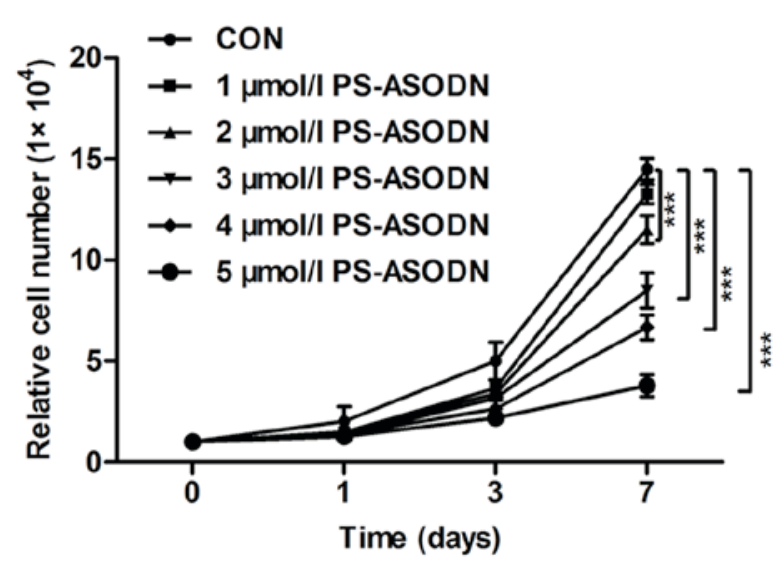

Figure 1. Inhibition of PS-ASODN on Walker 256 cell proliferation. Cells were treated with PS-ASODN at final concentrations of $0,1,2,3,4,5 \mu \mathrm{mol} / 1$ for 1,3 and 7 days, respectively. Data are presented as the mean \pm standard deviationof three independent experiments. ${ }^{* * * *} \mathrm{P}<0.001$ compared with $\mathrm{CON}$ group at the same time point. PS-ASODN, phosphorothioate modified antisense oligonucleotides; CON, control.

A

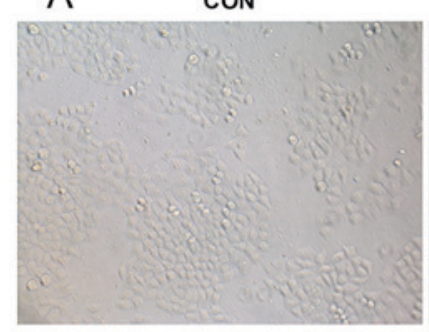

$\mathrm{B}$

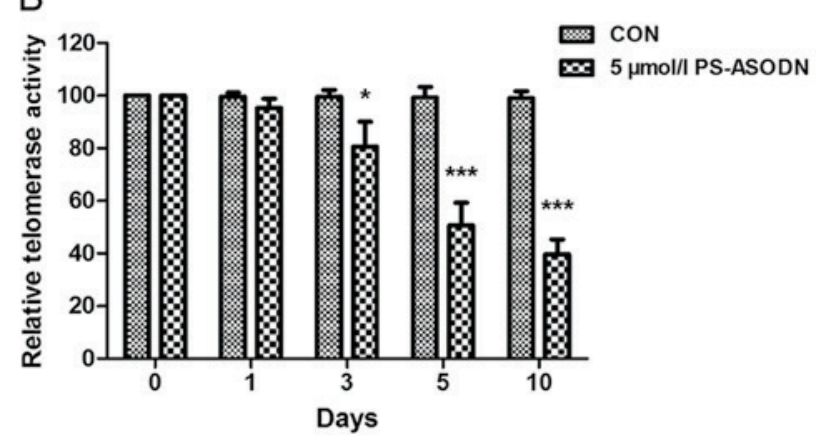

Figure 2. Acceleration of PS-ASODN on Walker 256 cell senescence by inhibiting telomerase activity. (A) SA- $\beta$-gal staining indicatingthe acceleration of PS-ASODN on Walker 256 cell senescence. (B) Inhibition of PS-ASODN on telomerase activity. Data are presented as the mean \pm standard deviationof three independent experiments. ${ }^{*} \mathrm{P}<0.05,{ }^{* * * *} \mathrm{P}<0.001$ vs. CON group at the same time point. PS-ASODN, phosphorothioate antisense oligonucleotides; CON, control.

activity was measured after treating Walker 256 cells with PS-ASODN ( $5 \mu \mathrm{mol} / 1)$ for 5 days. As presented in Fig. 2A, PS-ASODN accelerated cell senescence.

Telomere shortening and the accumulation of dysfunctional telomeres are associated with cell senescence $(11,12)$. Therefore, following treatment of Walker 256 cells with PS-ASODN $(5 \mu \mathrm{mol} / \mathrm{l})$, the effect of PS-ASODN on telomerase activity was determined. As presented in Fig. 2B, PS-ASODN resulted in a time-dependent decrease in telomerase activity,

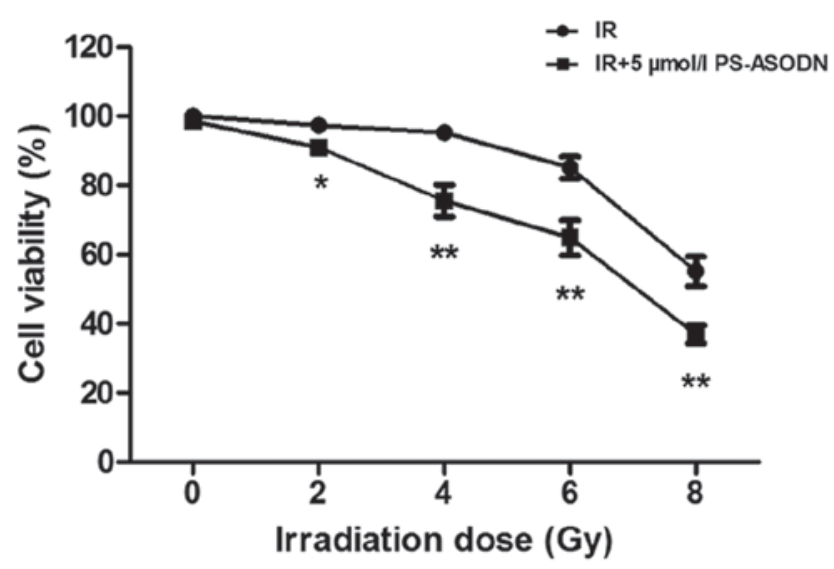

Figure 3. PS-ASODN enhances the inhibition of IRon cell viability. Walker 256 cells were treated with $5 \mu \mathrm{mol} / 1$ PS-ASODN and 0, 2, 4, 6 and $8 \mathrm{~Gy}$. Data are presented as the mean \pm standard deviationof three independent experiments. ${ }^{*} \mathrm{P}<0.05$ and $^{* *} \mathrm{P}<0.01$ vs. IR groupat the same dose. PS-ASODN, phosphorothioate modified antisense oligonucleotides; IR, irradiation.

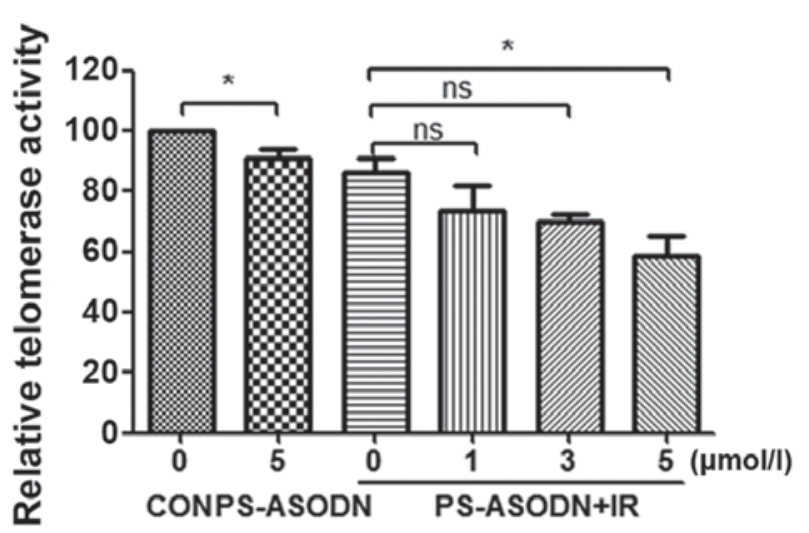

Figure 4. PS-ASODN enhances the inhibition of IRon telomerase activity. Walker 256 cells were treated with PS-ASODN at final concentrations of 0,1 , $3,5 \mu \mathrm{mol} / 1$ and IRat doses of $6 \mathrm{~Gy}$. Data are presented as the mean \pm standard deviationof three independent experiments. ${ }^{*} \mathrm{P}<0.05$. PS-ASODN, phosphorothioate modified antisense oligonucleotides; IR, irradiation; CON, control.

indicating that PS-ASODN promoted cell senescence by inhibiting telomerase activity.

Enhancement of PS-ASODN on cell sensitivity to IR. In order to evaluate the effect of PS-ASODN on radio sensitization of cells, the cell viability was examined by MTT assay. As presented in Fig. 3, PS-ASODN enhanced the inhibition of IRon cell viability. In addition, PS-ASODN was also identified to improve the inhibition of IR on telomerase activity (Fig. 4).

The apoptosis of Walker 256 cells was further analyzed by flow cytometry. Compared with the control group, the apoptosis rate of PS-ASODN treatment group increased significantly (Fig. 5A), indicating that PS-ASODN may induce cell apoptosis. Compared with the IR treatment group, the apoptosis rate of Walker 256 cells treated with PS-ASODN and IR increased as the PS-ASODN concentration increased (Fig. 5A), suggesting that PS-ASODN promoted IR-induced cell apoptosis. In addition, the results of western blotting indicated 

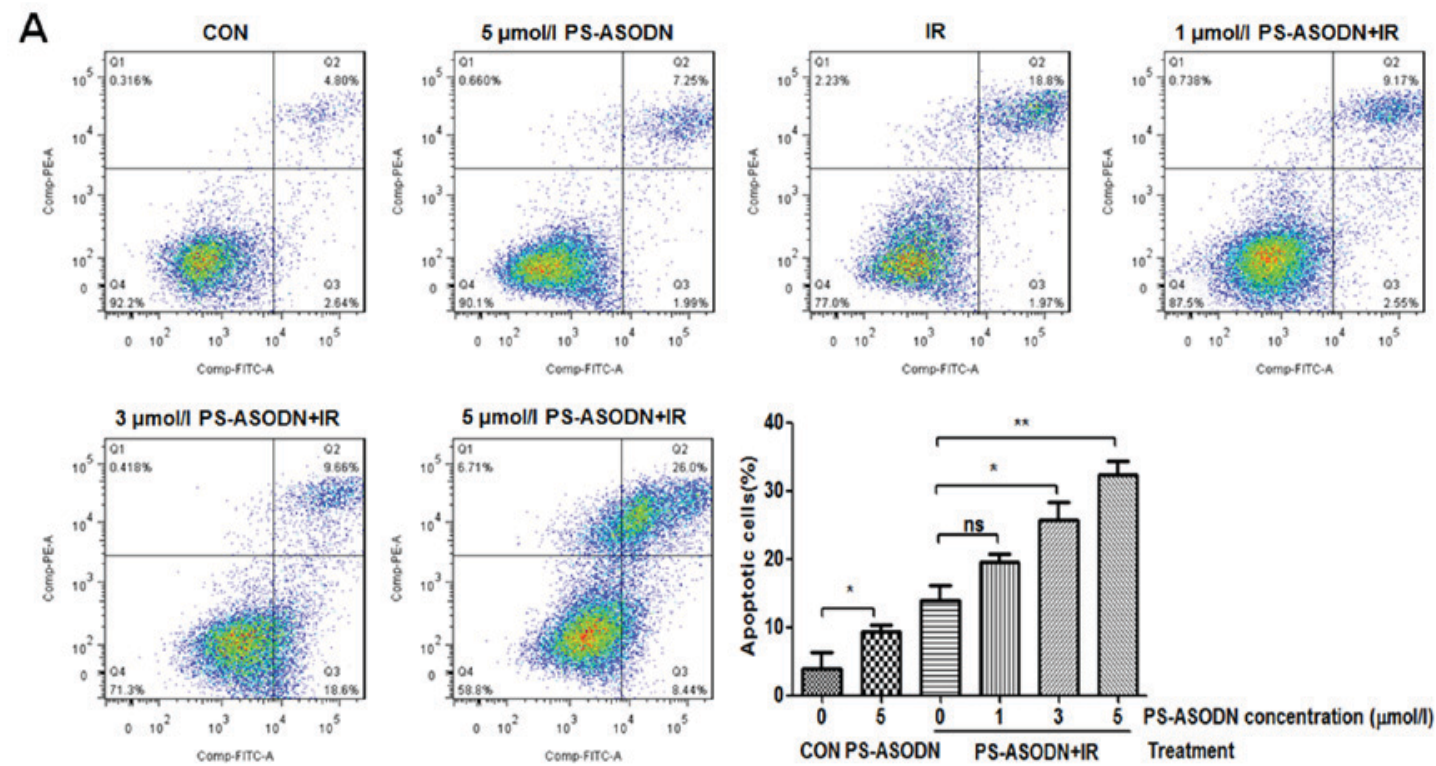

B

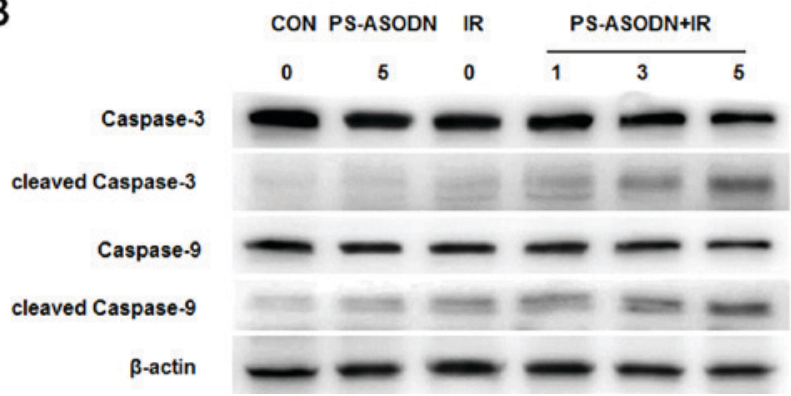

Figure 5. PS-ASODN promotes the induction of IRon cell apoptosis by activating apoptosis-associated proteins. (A) PS-ASODN enhances the induction of IRon cell apoptosis. (B) Caspase-3, cleaved caspase-3, caspase-9 and cleaved caspase-9 protein expression were determined by western blotting. $\beta$-actin was used as an internal control. Data are presented as the mean \pm standard deviationof three independent experiments. ${ }^{*} \mathrm{P}<0.05,{ }^{* *} \mathrm{P}<0.01$. PS-ASODN, phosphorothioate modified antisense oligonucleotides; IR, irradiation; CON, control.

CON

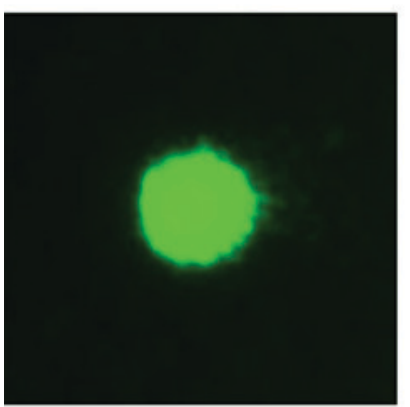

$3 \mu \mathrm{mol} / \mathrm{I}$ PS-ASODN+IR

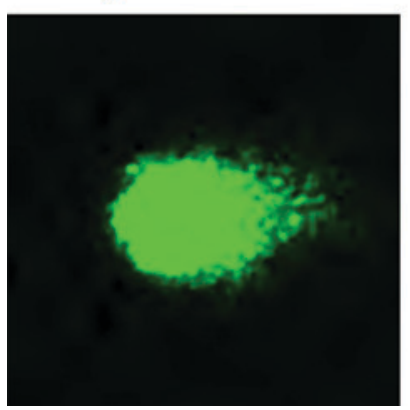

$5 \mu \mathrm{mol} / \mathrm{l}$ PS-ASODN

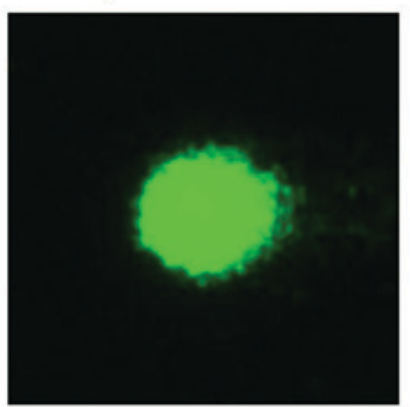

$5 \mu \mathrm{mol} / \mathrm{l}$ PS-ASODN+IR

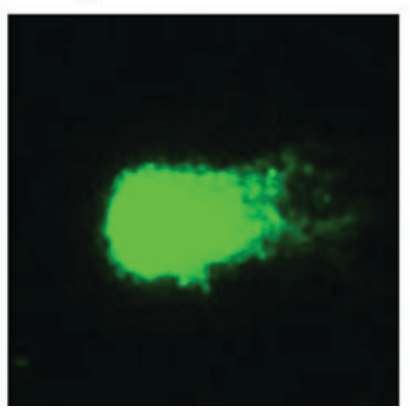

IR
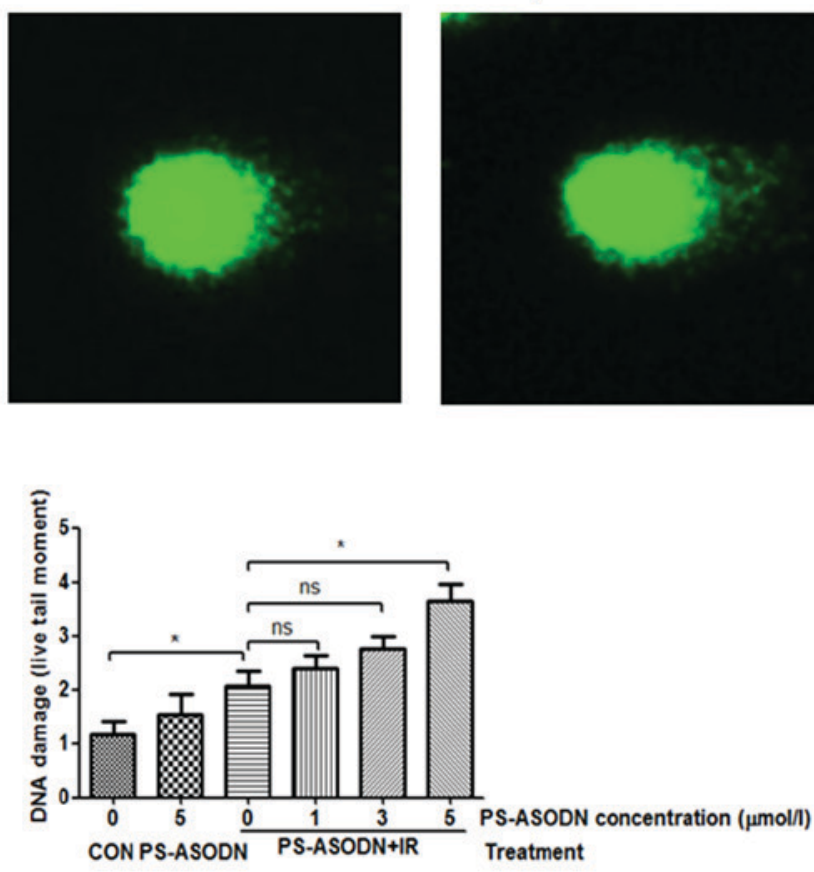

Figure 6. PS-ASODN enhances the induction of IRon DNA damage. Walker 256 cells were treated with PS-ASODN at final concentrations of $0,1,3$ and $5 \mu \mathrm{mol} / 1$ and IR at doses of $6 \mathrm{~Gy}$. Data are presented as the mean \pm standard deviationof three independent experiments. "P<0.05. PS-ASODN, phosphorothioate modified antisense oligonucleotides; IR, irradiation; CON, control. 
that combined treatment of PS-ASODN with IR resulted in increased protein expression levels of cleaved caspase- 3 and cleaved caspase-9 in the Walker 256 cells (Fig. 5B), thus indicating that combined treatment of PS-ASODN with IR promoted activation of cleaved caspase-3/9 in the apoptotic signaling pathway.

To confirm the effect of PS-ASODN on IR-induced DNA damage, the comet assay was performed to assess degree of DNA damage. Compared with IR treatment group, the DNA damage of Walker 256 cells treated with PS-ASODN and IR increased as the PS-ASODN concentration increased at $5 \mu \mathrm{mol} / 1$ (Fig. 6), suggesting that PS-ASODN enhanced IR-induced DNA damage.

Taken together, these observations suggested that effect of PS-ASODN may improve Walker 256 cell sensitivity to IR.

\section{Discussion}

As a special type of RNA nuclear protease, telomerase maintains the function of the telomere and servesan important role in cell senescence and carcinogenesis. It was reported that high telomerase activity has been identifiedin malignant tumors, and low telomerase activity has been identifiedin the majority of normal tissues and benign tumors (13). hTERT is a subunit of telomerase and its expression levels are indicated to be associated with telomerase activity (14-16). Therefore, it is suggested that hTERT may be an appropriate target for anti-sense therapy.

ASODN has become a research focus due to its high specificity, targeting and low toxicity, and may be applied to gene therapy (7). ASODNs are short DNA sequences that hybridize to complementary mRNA sequences based on Watson-Crick base pairing. ASODN gene therapy has been identifiedto effectively target the expression of genes involved in causing cancer, tumor growth inhibition, radiosensitization or chemosensitization (17-20). However, because ASODNs exhibit poor solubility, low affinity for their target complementary RNA sequences (21), phosphorothioate modification was adopted for ASODN in the current study. PS-ASODN presents with good aqueous solubility, increased resistance to degradation of oligodeoxynucleotide by nuclease, increased stability and liposome encapsulation $(7,22)$. Previous studies have demonstrated that PS-ASOND suppressed the activity of telomerase and tumor growth (23-27).

In the current study, PS-ASODN was demonstrated to have an inhibitory effect on cell proliferation in a time-dependent manner. PS-ASODN accelerated cell senescence and resulted in a time-dependent decrease in telomerase activity, indicating that PS-ASODN improved cell senescence by suppressing telomerase activity. Through treating Walker 256 cells with PS-ASODN and IR in combination, it was identified that PS-ASODN may enhance the inhibition of IRon cell viability and telomerase activity. Besides, PS-ASODN also promoted the induction of IRon cell apoptosis by activating apoptosis-associated proteins, and enhanced the induction of IRon DNA damage.

In conclusion, it is suggested that hTERT PS-ASODN, the inhibitor of telomerase activity, can inhibit cell proliferation, accelerate cell senescence by down-regulating telomerase activity, and enhance the inhibition of IRon cell viability and induction of IRon cell apoptosis and DNA damage, thus resulting in increased sensitivity to IR. These observations suggest that combination of PS-ASODN and IR is of significance in providing an experimental foundation for gene therapy and guiding the radio therapeutic strategy for cancer treatment.

\section{Acknowledgements}

The current study was supported by the National Natural Science Foundation of China (grant no. 81171435).

\section{References}

1. Jemal A, Center MM, DeSantis C and Ward EM: Global patterns of cancer incidence and mortality rates and trends. Cancer Epidemiol Biomarkers Prev 19: 1893-1907, 2010.

2. Siegel RL, Miller KD and Jemal A: Cancer statistics, 2016. CA Cancer J Clin 66: 7-30, 2016.

3. Lebedeva IV and Stein CA: Antisense oligonucleotides in cancer: Recent advances. BioDrugs 13: 195-216, 2000.

4. Walther W and Schlag PM: Current status of gene therapy for cancer. Curr Opin Oncol 25: 659-664, 2013.

5. Nittis T, Guittat L and Stewart SA: Alternative lengthening of telomeres (ALT) and chromatin: Is there a connection? Biochimie 90: 5-12, 2008.

6. Rao YK, Kao TY, Wu MF, Ko JL and Tzeng YM: Identification of small molecule inhibitors of telomerase activity through transcriptional regulation of hTERT and calcium induction pathway in human lung adenocarcinoma A549 cells. Bioorg Med Chem 18: 6987-6994, 2010.

7. Fan XK, Yan RH, Li BJ, Chen XM, Wei L and Wang Z: Antisense oligodeoxynucleotide against human telomerase reverse transcriptase inhibits the proliferation of Eca-109 esophageal carcinoma cells. Exp Ther Med 8: 1247-1252, 2014.

8. Ponnala S, Chetty C, Veeravalli KK, Dinh DH, Klopfenstein JD and Rao JS: MMP-9 silencing regulates hTERT expression via $\beta 1$ integrin-mediated FAK signaling and induces senescence in glioma xenograft cells. Cell Signal 23: 2065-2075, 2011.

9. Folini M, Brambilla C, Villa R, Gandellini P, Vignati S, Paduano F, Daidone MG and Zaffaroni N: Antisense oligonucleotide-mediated inhibition of hTERT, but not hTERC, induces rapid cell growth decline and apoptosis in the absence of telomere shortening in human prostate cancer cells. Eur J Cancer 41: 624-634, 2005.

10. Kraemer K, Fuessel S, Schmidt U, Kotzsch M, Schwenzer B, Wirth MP and Meye A: Antisense-mediated hTERT inhibition specifically reduces the growth of human bladder cancer cells. Clin Cancer Res 9: 3794-3800, 2003.

11. Sekoguchi S, Nakajima T, Moriguchi M, Jo M, Nishikawa T, Katagishi T, Kimura H, Minami M, Itoh Y, Kagawa K, et al: Role of cell-cycle turnover and oxidative stress in telomere shortening and cellular senescence in patients with chronic hepatitis C. J Gastroenterol Hepatol 22: 182-190, 2007.

12. Kaul Z, Cesare AJ, Huschtscha LI, Neumann AA and Reddel RR: Five dysfunctional telomeres predict onset of senescence in human cells. EMBO Rep 13: 52-59, 2011.

13. Kim NW, Piatyszek MA, Prowse KR, Harley CB, West MD, Ho PL, Coviello GM, Wright WE, Weinrich SL and Shay JW: Specific association of human telomerase activity with immortal cells and cancer. Science 266: 2011-2015, 1994.

14. Sekaran VG, Soares J and Jarstfer MB: Structures of telomerase subunits provide functional insights. Biochim Biophys Acta 1804: 1190-1201, 2010.

15. Donate LE and Blasco MA: Telomeres in cancer and ageing. Philos Trans R Soc Lond B Biol Sci 366: 76-84, 2011.

16. Zvereva MI, Shcherbakova DM and Dontsova OA: Telomerase: Structure, functions, and activity regulation. Biochemistry (Mosc) 75: 1563-1583, 2010.

17. Agrawal A, Dang S and Gabrani R: Recent patents on anti-telomerase cancer therapy. Recent Pat Anticancer Drug Discov 7: 102-117, 2012.

18. Nakhlband A, Barar J, Bidmeshkipour A, Heidari HR and Omidi Y: Bioimpacts of anti epidermal growth factor receptor antisense complexed with polyamidoamine dendrimers in human lung epithelial adenocarcinoma cells. J Biomed Nanotechnol 6: 360-369, 2010. 
19. Zhao FJ, Zhang SL, Ma L, Gao H and Zong ZH: Inhibitory effects of c-erbB-2 antisense oligonucleotide transfection on uterine endometrial cancer Ishikawa cell lines. Eur J Gynaecol Oncol 30: 54-59, 2009.

20. Loriot Y, Mordant P, Brown BD, Bourhis J, Soria JC and Deutsch E: Inhibition of BCL-2 in small cell lung cancer cell lines with oblimersen, an antisense BCL-2 oligodeoxynucleotide (ODN): In vitro and in vivo enhancement of radiation response. Anticancer Res 30: 3869-3878, 2010.

21. Zhang KZ, Xu JH, Huang XW, Wu LX, Su Y and Chen YZ: Curcumin synergistically augments bcr/abl phosphorothioate antisense oligonucleotides to inhibit growth of chronic myelogenous leukemia cells. Acta Pharmacol Sin 28: 105-110, 2007.

22. Yuan Y, Cai H, Yang XJ, Li W, He J, Guo TK and Chen YR: Liposome-mediated induction of apoptosis of human hepatoma cells by c-myc antisense phosphorothioate oligodeoxynucleotide and 5-fluorouracil. Asian Pac J Cancer Prev 15: 5529-5533, 2014.

23. Svinareva LV, Glukhov AI, Moskaleva EY and Shvets VI: Effect of modified DNA and RNA oligonucleotides on telomerase activity and tumor cell survival in vitro. Appl Biochem Micro 47: 718-722, 2011.
24. Wang XS, Wang K, Li X and Fu SB: Effects of phosphorothioate anti-sense oligodeoxynucleotides on colorectal cancer cell growth and telomerase activity. World J Gastroenterol 10: 3455-3458, 2004.

25. Gao XD and Chen YR: Inhibition of telomerase with human telomerase reverse transcriptase antisense increases the sensitivity of tumor necrosis factor-alpha-induced apoptosis in prostate cancer cells. Asian J Androl 9: 697-704, 2007.

26. Ji XM, Xie CH, Fang MH, Zhou FX, Zhang WJ, Zhang MS and Zhou YF: Efficient inhibition of human telomerase activity by antisense oligonucleotides sensitizes cancer cells to radiotherapy. Acta Pharmacol Sin 27: 1185-1191, 2006.

27. Fan XK, Yan RH, Li BJ, Chen XM, Wei L and Wang Z: Antisense oligodeoxynucleotide against human telomerase reverse transcriptase inhibits the proliferation of Eca-109 esophageal carcinoma cells. Exp Ther Med 8: 1247-1252, 2014. 